\title{
4. Another Canon, Another Time
}

\author{
The Novelizations of the Star Wars Films
}

Thomas Van Parys

It was not written in the stars that a small novel based on an eclectic film screenplay and ghostwritten as work-for-hire would have such an impact on the process and practice of adapting films into novels. Thanks to the film's box-office success, the novelization of $A$ New Hope (1976) has arguably had a major influence on film novelizations as a genre. When David Seltzer's The Omen (1976) unexpectedly became a financial hit and went to the \#1 spot in the United States, book publishers realized that, in addition to functioning as a marketing tool, novelizations could be bestsellers in their own right. Thus, while novelizations have been around since the birth of cinema, the arrival of Star Wars cemented their institutionalization in Hollywood. That is, to the extent that this was not yet the case, the practice of novelizing the latest potential blockbuster hit became an established part of film marketing and media franchising. Moreover, the amount and visibility of science-fiction novelizations increased as science-fiction cinema boomed, while in the tie-in market, science-fiction novelizations became more prominent because more films were increasingly based on original screenplays, in contrast with the many adaptations from book to film that took place in the 1950 s and 196os.

The novelization of A New Hope and the ensuing Star Wars novelizations and franchise novels ${ }^{1}$ also had lasting effects on science-fiction literature, as original science-fiction novels now had to contend with the success of the innumerable spin-off novels of various franchises, to the dismay of many science-fiction authors and critics. Science-fiction cinema was long considered inferior to science-fiction literature, due to the supposed mediocrity of its ideas; science-fiction novelizations therefore constituted the bottom of the barrel. James Gunn even contends that science-fiction films "translated into written form, would be unpublishable because of lack

1 See Sean Guynes's chapter in this volume on the media-industrial history of Star Wars franchise novels. 
of logic or originality," regardless of "the success of the novelized versions of a variety of SF [science-fiction] films, including $A$ New Hope and its sequels."

Throughout its history, the novelization has had a double goal: it is both promotional material for the film and a prolongation of the film experience to capitalize on its (potential) success. A novelization can function as a spoiler (before the film viewing) and as an expansion or elaboration (after the film viewing). Fans may want to read a novelization to access extras, such as character elaborations or altered, extended, and deleted sequences, which are fixtures of novelizations since they are usually based on an early version of the shooting script.

In this chapter, I focus on how the novelizations of the seven main Star Wars films, ${ }^{3}$ which I will discuss in publication order, add to the worldbuilding of the transmedia universe. I argue that they largely evolve from minimal and faithful reworkings of the screenplay to explanatory elaborations that occasionally provide key insights into character motivations. This also reflects how the contexts of the different film productions influenced individual novelizers' approaches: perhaps paradoxically, as the Star Wars transmedia franchise is developed over time, Lucasfilm has exerted greater control over Star Wars literature, yet at the same time, novelizers have been given more leeway. The novelizations also display self-awareness of their transmedial function within the Star Wars mega-text by mythologizing the narrative and connecting with the previous films and even with earlier novels. In this way, they draw attention to their double status as novelizations and chapters of a serialized story.

2 James E. Gunn, “The Tinsel Screen," in Projections: Science Fiction in Literature and Film, ed. Lou Anders (Austin,TX: MonkeyBrain Books, 2004), 45.

3 These seven novels are obviously not the only novelizations of the films. For the original trilogy, other publications include storybooks (adapted by Geraldine Richelson, Shep Steneman, and Joan D. Vinge, respectively and collected in Star Wars - The First Ten Years: Movie Storybook Trilogy), Step-Up Movie Adventure books (A New Hope and The Empire Strikes Back adapted by Larry Weinberg, Return of the Jedi by Elizabeth Levy), and even "Book and Record" sets ("SEE the pictures, HEAR the record, READ the book"). The most curious tie-ins are perhaps the Special Young Readers' Edition novelizations, which are basically edited-down, rather than rewritten, versions of the original novelizations. These novels are virtually identical—same format, similar cover-only shorter. In 2004, Scholastic retroactively published original junior novelizations by Ryder Windham to coincide with the original trilogy's DVD release. For the prequel trilogy, a similar range of books exists: Scholastic published junior novelizations written by Patricia Wrede and, in 2017, Disney released "Read-Along Storybook and CD" sets. Further engaging a younger interactive audience, the The Phantom Menace journals and the Star Wars Adventures book series, which includes regular novels alongside corresponding game books, contain partial novelizations of The Phantom Menace as well. 


\section{A New Hope}

Publishing Star Wars spin-off novels was a franchising strategy from the beginning. As part of publicity supervisor Charles Lippincott's marketing plan, a deal was made with Ballantine Books for the publication of five Star Wars books: two novels, two "making of" books, and a calendar. ${ }^{4}$ Published as Star Wars: From the Adventures of Luke Skywalker with a cover design by Ralph McQuarrie, the novelization of $A$ New Hope first appeared in December 1976, five months before the film was released. This pre-release was partially due to a shift in the film's release date and partially because Lippincott wanted science-fiction fans to get to know the story and spread the word. The paperback hit the bestseller list and its print run of 250,000 copies sold out by February. In other words, the novelization was not just a book that benefited from the popularity of the film; in its own way, it contributed to that success. According to Ballantine, 3.5 million copies were sold in three months, ${ }^{5}$ making it the fourth biggest bestseller in America.

Famously, the novel is credited to George Lucas, but was in fact ghostwritten by Alan Dean Foster. Foster is recognized by fans and the publishing industry as the novelizer par excellence, always mentioned first in any list. Given his reputation, it is not surprising that he has the highest number of hit science-fiction film novelizations to his name. "If you do something and it sells umpteen zillion copies, then the next person who comes along will look to you as a logical choice to possibly sell umpteen zillion copies of their book," Foster says. ${ }^{6}$ Among many other novelizations, he wrote Alien (1979), The Thing (1981), Transformers (2007), Terminator: Salvation (2009), and Star Trek (2009). He is also the author of many franchise novels that build upon the worlds of those films, most famously Splinter of the Mind's Eye (1978), a semi-novelization-turned-sequel to A New Hope that was part of the Ballantine book deal (see Matthew Freeman's chapter in this volume).

Hired by Judy Lynn Del Rey, editor of Ballantine's science-fiction line, Foster's experience on A New Hope's novelization was a happy one; Foster had a brief meeting with George Lucas and thought "he was the nicest

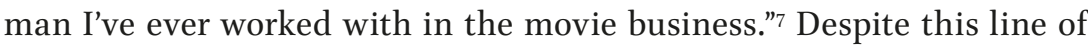
communication between director and novelizer, the novel is a prototypical

4 Chris Taylor, How Star Wars Conquered the Universe: The Past, Present, and Future of a Multibillion Dollar Franchise (New York: Basic Books, 2015), 158-160.

5 David Pringle, “SF, Fantasy \& Horror Movie Novelizations," Interzone 80 (1994): 40.

6 Randall D. Larson, Films into Books: An Analytical Bibliography of Film Novelizations, Movie, and TV Tie-Ins (Metuchen, NJ: The Scarecrow Press, 1995), 141.

7 Larson, Films into Books, 142. 
example of the commercial novelization, in that it sticks closely to the screenplay, offers minimal extra characterization, features a third-person omniscient narrator with many displacements of focus and sudden cuts to new paragraphs, and tells the story concisely. In this way, Foster set the template for the novelizations of the original trilogy, which are adaptations mostly placed outside the production context of the films and basically limited to transcriptions of the screenplays, with occasional additions.

In this novelization, the most significant bonus is the short prologue, which effectively mythologizes the story. Presented as an excerpt "From the First Saga/Journal of the Whills" — which Lucas was originally going to use to connect his Star Wars universe to our world-and accompanied by a quote ascribed to Leia Organa of Alderaan, Senator ("They were in the wrong place at the wrong time. Naturally they became heroes." $\left.{ }^{\prime}\right)$, the prologue briefly recounts the background to A New Hope. As Lucasfilm's Pablo Hidalgo points out, "[f] or decades, this 362 -word introduction served as the only real insight into the events potentially covered in Episodes I, II, and III,"9 and it already embeds into the story the politics for which the prequel trilogy would later be so heavily criticized by fans.

In this prologue, Emperor Palpatine "was controlled by the very assistants and boot-lickers he had appointed to high office" instead of the other way around, and it is the Imperial bureaucrats that had "exterminated through treachery and deception the Jedi Knights. ${ }^{{ }^{10}}$ As this was written before Star Wars became a phenomenon and an expansive storyworld, there are bound to be surprising differences, from how the story would develop to now famous lines (e.g. "I have a very strange feeling about this"11) and so on. For the opening sentence, Foster replaced "A long time ago in a galaxy far, far away" with "Another galaxy, another time, ${ }^{12}$ arguably missing the point of Lucas's line, which goes counter to expectation by setting the narrative explicitly in the past. However, from a certain point of view, the Star Wars novelizations are set in yet another galaxy than the films, as we shall see. In some ways, they enrich both the Star Wars universe and the films; in other ways they are hybrid, anachronistic objects that do not always rhyme with that universe and never constitute fully fledged texts on their own-now as well as then.

8 George Lucas, Star Wars (London: Sphere Books Limited, 1977), 6.

9 Pablo Hidalgo, Star Wars: The Essential Reader's Companion (New York: Ballantine Books, 2012), 182.

10 Lucas, Star Wars, 5.

11 Lucas, Star Wars, 112.

12 Lucas, Star Wars, 5. 


\title{
The Empire Strikes Back
}

The novelization of The Empire Strikes Back (1980) was written by Donald F. Glut, a friend of George Lucas's at film school and originally the first to be asked to write $A$ New Hope's novelization. But Glut had refused because the pay was low, there were no royalties, and Twentieth Century Fox wanted Lucas's name on the cover. The novelization of The Empire Strikes Back was released a week in advance of the film and sold three million copies. ${ }^{13}$ Glut's novelization experience was rather less positive than Foster's, as Lucasfilm's policy of secrecy and control around the production of the sequel hindered his writing:

\begin{abstract}
"Some people could look at the scripts but not see the artwork; some people could see the artwork but not the scripts. They literally locked me inside a trailer with all the McQuarrie paintings." He made sketches in a notebook and remembered showing an employee one sketch when he came out. "Is this Yoda?" Glut asked. The employee threw his hands over his eyes. "Don't tell me! I don't want to know."
\end{abstract}

Indeed, in the novel, Yoda has long white hair on his "blue-skinned head," ${ }^{15}$ which matches early concept art of the character ${ }^{16}$ It is also clear that Glut's interpretation of the Han Solo character is different from Harrison Ford's portrayal. Since he did not have access to any film footage, Glut "was worried that the book would be a lot different than the movie and would offend a lot of readers": "all I had to go by, as far as the mood and the visual style, was the first film. So I tried to apply what I remembered from the first film to the novel of the second film." ${ }^{17}$

In a sense, this novel may be regarded as a double adaptation-with the story and dialogue novelized from the script and most of the visual imagery adapted from the previous film and McQuarrie's concept art. At the beginning of the novel, Glut explicitly references A New Hope a few times, effectively recapping the previous film: 
The job had seemed simple enough:just pilot Ben Kenobi, plus young Luke and two droids, to the Alderaan system. How could Han have known at the time that he would also be called on to rescue a princess from the Empire's most feared battle station, the Death Star? ${ }^{18}$

Indicating how novelizers do not just transcribe the screenplay but draw on different sources and media (such as conversations with the director, previous film installments, artwork, publicity photos, and so on), these examples reinforce the evolution of Star Wars from an individual story to a serialized story universe. The novelization also ends with a prefiguration of Return of the Jedi's plot: "[Luke] only knew he had to return to Yoda and finish his training before he set off to rescue Han." ${ }^{19}$

Whereas other novels might include small bonuses for fans with insight into events or characters, Glut does not offer much additional interpretation. This may be traced back to the novelization's production constraints, but ironically, the main reason for the film producers' paranoia-Darth Vader's identity as Luke's father - would indeed be given away beforehand by the novelization itself.

\section{Return of the Jedi}

For the novelization of Return of the Jedi (1983), author James Kahn was not allowed much "literary freedom" ${ }^{20}$ either. With additional character backgrounds being rejected, Kahn had to follow the screenplay closely, more so for Return of the Jedi than for other novelizations. The following quote may be read as subtle metafictional commentary on the restrictions of the novelizer's job:

This did not scan at all. Someone had obviously mislaid the correct program. Nonetheless, he was only a droid, his functions well delineated. Translation only, no free will please. He shook his head and continued..$^{21}$

In another instance, Kahn virtually makes fun of the (heavily criticized) twist that Leia turns out to be Luke's sister: 
Pawn in a castle conspiracy? Cribs mixed, siblings switched and parted and whisked away to different secret lives? Impossible. He knew who he was! He was Luke Skywalker. ${ }^{22}$

It is, in fact, not unusual for novelizers to insert the occasional comment on filmic logic or the film's plot. As these examples illustrate, the constraints of the novelization are countered with a literary style that can be described as more specific, adult, self-conscious, humorous, and at times metaphorical. What is more, Kahn elaborates throughout on characters' motivations and the thoughts behind their actions. In this way, by systematically providing access to the characters' reflections, Kahn also makes both Luke's nearseduction to the dark side and the redemption of Darth Vader more plausible than in the film:

Luke didn't bury the thought, this time; he gloried in it. He engorged himself with its juices, felt its power tingle his cheeks. It made him feverish, this thought, with lust so overpowering as to totally obliterate all other considerations. ${ }^{23}$

Kahn tries to find the logic behind every question that might arise from the film's story and plot.

In a sense, the increased focus on character development and plot consistency may be the main reason for fans to read this particular novelization. On the one hand, the novel provides an alternative, expanded experience with a couple of "Easter eggs" thrown in; the multiple references to the Star Wars mega-text, which are always functional here in terms of characterization, are part of that:

And so Senator Palpatine had seized the moment. Through fraud, clever promises, and astute political maneuvering, he'd managed to get himself elected head of the Council. And then through subterfuge, bribery and terror, he'd named himself Emperor. ${ }^{24}$

The novel also provides the first clue to how Anakin Skywalker transformed into Darth Vader: "Memories of molten lava, crawling up his back ... no." ${ }^{25}$ 
Even though these references also contain elements that would later be retconned, they position the novel within a larger mythology, and again include early hints of where the story would ultimately lead (back to). On the other hand, the novelization functions as a corrective text that tries to counter what Kahn perceived to be the film's flaws. In this way, the text can be read as an attempt to respond to every fan's impossible wish regarding every Star Wars film after the irreproachable The Empire Strikes Back, namely to redo the Star Wars sequel in question as it should have been done.

\section{The Prequel Trilogy}

By the time of The Phantom Menace's novelization (1999), Lucasfilm's policy regarding adaptation had changed. At the end of the 1980s, when there were virtually no new Star Wars-related media on the market, Bantam proposed starting a series of Star Wars novels, commissioning Timothy Zahn to write a sequel trilogy. While they began to churn out a deluge of franchise novels of varying quality very quickly, the original idea was, in fact, to produce one well-written hardback a year that would be marketed as a movie-like event. ${ }^{26}$ The success of these franchise novels made Lucasfilm pay more attention to Star Wars literature: they started to exert more control with an eye to Star Wars canon (even though the rule was that anything could be contradicted by film or television work authorized by Lucas), but Bantam's success with Star Wars franchise novels did influence their approach to the novelizations of the prequel trilogy.

While The Phantom Menace has all the hallmarks of commercial fiction - the novel was a predestined bestseller and was released with four different covers the fans could collect ${ }^{27}$ - it also attempts to increase its literary prestige: the novelization was longer than the typical screenplay transcription, it was "the first Star Wars movie novelization to add newly created scenes unique to the book, ${ }^{28}$ and it was written by Terry Brooks, a bestselling author of fantasy novels. Like Star Wars novelizers before him, Brooks received direct input from George Lucas, but the additional material is more substantive than in previous novelizations: going further than

26 Taylor, How Star Wars Conquered the Universe, 288.

27 For an analysis of the novelization as a bestseller, see http://bestsellers.lib.virginia.edu/ submissions/344.

28 Hidalgo, Star Wars: The Essential Reader's Companion, $5^{\circ}$. 
Kahn's Return of the Jedi, it provides many explanations and motivations, and plentiful characterization. The novel features more background on the Jedi Order and the Sith (all of which has since been expanded in franchise novels, comics, and video games) and even includes a new beginning and a new sequence involving Anakin Skywalker, who consequently becomes more central to the story.

The Phantom Menace's novelization was clearly used as a template for the next novelizations in scale, ambition, and approach. Continuing the established tradition, these novelizations were written by different authors. Science-fiction and fantasy author R.A. Salvatore's novelization of Attack of the Clones (2002) again contains exclusive sequences: the first three chapters, for instance, mainly deal with the abduction of Anakin's mother, Shmi Skywalker. The novel also features plenty of direct references to the other films, such as a mid-novel, one-page recapitulation: "that reminded Obi-Wan of the difficult circumstances under which Anakin had entered the Order." ${ }^{29}$ In the description of Obi-Wan Kenobi- "Obi-Wan's wheatcolored hair was longer now, hanging loosely about his shoulders" ${ }^{3^{\circ}}$ - the word "now" is deictic and explicitly appeals to the reader's familiarity with The Phantom Menace. At one instance, Salvatore even refers to a sequence from the previous novelization (in which Anakin saves the life of a Tusken Raider) that is not present in the corresponding film:

He'd had some experience with Tusken Raiders, but on a very limited basis. Once he had tended the wound of one gravely injured Raider, and when the Tusken's friends showed up, they had let him go-something unheard of among the more civilized species of Tatooine. ${ }^{31}$

This exceptional reference to another novelization (rather than to the films) is all the more striking because it seems to serve no practical purpose here. The context even seems opposite to the recapitulated situation, but it does help to flesh out Anakin's biography.

Taking the usual nods to the Star Wars mega-text one step further, Matthew Stover's Revenge of the Sith novelization (2005) continually refers to the previous and next episodes, and even includes many instances of more obscure references to other texts in the transmedia universe to the extent that the novel can only be fully understood by the knowledgeable Star 
Wars fan: "Flying, he could forget about his slavery, about his mother, about Geonosis and Jabiim, Aargonar and Muunilinst and all the catastrophes of this brutal war." ${ }^{32}$ Stover's fan service has paid off, as the novel is allegedly "a minor classic, much beloved by fans," not in the least because it elucidates Anakin's turn to the dark side. ${ }^{33}$ Like Kahn's Return of the Jedi, it tries to correct perceived flaws in the film. According to Hidalgo, "its greatest additions to the screenplay are extensive internal viewpoints exploring the psychological underpinnings to character actions. ${ }^{{ }^{34}}$ In effect, the novel seems to be the culmination of the strategies in the previously discussed novelizations: there is extensive additional material and characterization, and every action is motivated. ${ }^{35}$

With the story of Revenge of the Sith revealed, the present catches up with the past for Star Wars fans. In a way, this is mirrored in the novel, which, as Hidalgo also notes, "often switches tenses and time frames to present the story as both an event of the past, and one 'currently' unfolding. ${ }^{136}$ This is already apparent on the opening page:

This story happened a long time ago in a galaxy far, far away. It is already over. Nothing can be done to change it. [...] It is the story of the end of an age. A strange thing about stories-Though this all happened so long ago and so far away that words cannot describe the time or the distance, it is also happening right now. Right here. It is happening as you read these words. This is how twenty-five millennia come to a close. [...] The end starts now. ${ }^{37}$

On the one hand, Stover builds upon, or even adapts, Lucas's mythologization of Star Wars as a story of the "used" past (rather than one set in the future). On the other hand, he draws attention to the novel's own status as a narrative: as a prequel, it is a story that was over before it even began, and there is nothing that the narrator can do to change its outcome. Moreover, although the novel is mostly written in the traditional past tense, these first lines shift the narrative to the present. Indeed, in several sequences, the reader is even put into the place of the characters: 
This is how it feels to be Anakin Skywalker, right now: You don't remember putting away your lightsaber. You don't remember moving from Palpatine's private office to his larger public one; [...] You remember only that the last man in the galaxy you still thought you could trust has been lying to you since the day you met. [...] Inside your head, there is only fire. Around your heart, the dragon whispers that all things die. This is how it feels to be Anakin Skywalker, right now. ${ }^{3}$

From this passage, which occurs right after the Emperor has revealed himself to Anakin, the viewer also cannot "remember" the actions, thoughts, and dialogue, as it does not occur in the final film. In this novelization, it is not important anymore to reproduce the film precisely; instead, it is meant to be a separate, enhanced experience. The shift to the present tense and second-person point of view also makes the novel reminiscent of a Choose Your Own Adventure book. Although the reader remains passive here, the novel offers an alternate version of the story. In this way, the novelization becomes part of the heavily intertextual and interactive Star Wars narrative, in which the franchise's readers/viewers/gamers pick and choose their own experiences amongst a plethora of heavily referential media tie-ins, and in which novelizations are only one of the myriad possibilities for storyworld engagement.

\section{The Force Awakens}

As The Force Awakens pays homage to and even recapitulates major narrative moments of A New Hope, it is fitting that the novelization of The Force Awakens also returns to the template of the first film's novelization and to its author, Alan Dean Foster. Besides the occasional addition, such as an introductory three pages, which retell the opening crawl, characteristic plot correction, and (pseudo-)scientific explanation-e.g., "the resulting graviton flux released enough heat to ignite the core [...] Turning the planet into what astrophysicists called a pocket nova"39_- the novelization sticks closely to the screenplay and film. While Foster's style and approach have remained the same, the constraints and control have been tightened: for The Force Awakens novelization, the "Lucasfilm Story Group vetted everything 
and while some of Foster's creations stayed in the book, others he was asked to take out."40

This can be connected to the changed production circumstances. When the franchise changed owners to Disney, the EU was reformulated as Star Wars Legends, but, even officially, the novelizations are a special case. As Del Rey tweeted, "movie novelizations are canon where they align with what is seen on screen in the 6 films and the Clone Wars animated movie."41 The lingering perceived irrelevance of novelizations (why read the book when you can see the film?) is mirrored here in the confusion about their canonicity. According to the new Lucasfilm Story Group's continuity standards, the novelizations do not seem to matter. Hidalgo, a member of the Story Group, for example, tweeted, "remember these novels have Luke as Blue Five, a blueskinned Yoda, and Owen as Ben's brother." ${ }^{12}$ Yet despite these continuity errors, the novelization cannot be retired as easily as the EU novels because of their strong association with the films. The novelizations still remain in print - bundled into two trilogy omnibuses - as historical documents or nostalgic "time capsules"33 from another galaxy, another time.

More significantly, the novelizations have been a testament to the changing attitude towards the storyworld and transmedia franchising strategies utilized throughout Star Wars history-an attitude that has strongly influenced the approach and constraints of each novel. The first novelization was written on the occasion of a one-off film event, with even its direct sequel (Foster's Splinter of the Mind's Eye) lacking input for a larger framework. The other two novelizations of the original trilogy had to deal with the secrecy surrounding those films' productions and just as the films had different directors, the novels were written by different authors. The expansion of the Star Wars storyworld through print fiction, as a way to maintain interest in the franchise, had become increasingly important by the time of the prequel trilogy. The prequels' novelizations thus have strong ties to other transmedia Star Wars texts and provide additional, then canonical, background. It is no surprise, then, that as Disney has reined in

40 Lisa Granshaw, "Star Wars: The Force Awakens Novelization: An Interview with Alan Dean Foster," Syfy Wire, January 22, 2016, accessed February 20, 2017, http://www.blastr.com/2016-1-22/ star-wars-force-awakens-novelization-interview-alan-dean-foster.

41 Star Wars Books (@DelReyStarWars), Twitter post, April 30, 2014, 11:54a.m., https://twitter. com/delreystarwars/status/461579307341840384.

42 Inside Sources (@pablohidalgo), Twitter post, December 24, 2015, 5:46p.m., https://twitter. com/pablohidalgo/status/680202967106994176.

43 Inside Sources (@pablohidalgo), Twitter post, December 24, 2015, 6:08p.m., https://twitter. com/pablohidalgo/status/68o208376156913664. 
and reset the storyworld, they have also returned to the original strategy so as not to spoil future ideas. In other words, the greater the potential, the greater the control over the transmedia content. As the cycle begins anew, it remains to be seen whether future novelizations will again be allowed to contribute value to the storyworld for readers and fans. 
